\title{
全方向ステレオシステムを搭載した移動体による 実環境からの動物体検出
}

$\begin{array}{llllll}\text { 非会員 } & \text { 清水 } & \text { 早苗*,** } & \text { 正 員 } & \text { 山本 } & \text { 和彦** } \\ \text { 非会員 } & \text { 王 } & \text { 彩華* } & \text { 非会員 } & \text { 佐藤 } & \text { 雄隆* } \\ \text { 非会員 } & \text { 棚橋 } & \text { 英樹*** } & \text { 非会員 } & \text { 丹羽 } & \text { 義典* }\end{array}$

Detection of Moving Object by Mobile Stereo Omni-directional System (SOS)

Sanae Shimizu*,**, Non-member, Kazuhiko Yamamoto**, Member, Caihua Wang*, Non-member, Yutaka Satoh*, Non-member, Hideki Tanahashi**, Non-member, Yoshinori Niwa*, Non-member

Moving object detection with a mobile image sensor is an important task in robotics and computer vision, when considering the practical use of robots in human environments. In this paper, we propose a robust method that detects moving objects in the environment using the omni-directional depth information obtained by a mobile Stereo Omni-directional System (SOS). In order to detect only the moving objects within the depth image that are obtained by a sensor in motion, we first estimate the ego-motion of the sensor, and generate a predicted depth image for the current time from the depth obtained at the previous time by only considering the ego-motion of the sensor. Then the predicted depth image is compared with the actual one obtained at the current time, and the inconsistent regions are detected as moving objects. When the senor moves, occlusions will occur in the scene and they will cause false detections. However, these false detections can be suppressed by estimating the occlusion regions using the ego-motion parameters of the sensor and the jump edges in the depth image. The effectiveness of the method is shown with the experiment results on a real environment.

キーワード：全方向画像，全方向ステレオ，移動体ビジョン，動物体検出

Keywords: omni-directional image, omni-directional stereo, mobile robot vision, moving-object detection

\section{1. まえがき}

人間共存型の移動ロボットを検討する場合 , 人間の生活 空間という複雑で，かつ時間的変化の大きい環境への適応 性が重要となる。特に，観測系が移動しつつ，他の動物体 を検出するための技術は，任意に歩き回る複数の人物など

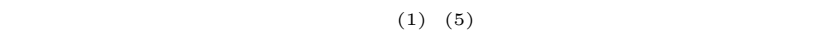
など , 人間と協調した動作を可能とするために重要である。

\footnotetext{
*(財) ソフトピアジャパン HOIP/JST

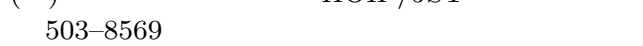

HOIP., Softopia Japan and JST,

4-1-7 Kagano, Ogaki-shi, Gifu 503-8569

** 岐阜大学工学研究科

于 501-1193 岐阜県岐阜市柳戶1-1

Faculty of Engineering., Gifu University,

1-1 Yanaido, Gifu-shi, Gifu 501-1193

*** 岐阜県生産情報技術研究所

₹ 509-0108 岐阜県各務原市須衛町 4丁目 179 番地の19

IMIT-Gifu.,

4-179-19 Sue-cho, Kagamigahara-shi, Gifu 509-0108
}

視覚センサは，広範囲の情報をリアルタイムに取得するこ とが可能であり，このような問題を効率よく解くために有 効である。

これまでに，観測系が移動しつつ，他の動物体を検出す るための方法として，樣々な手法が提案されている。これ らの手法は，画像から得られるオプティカルフローを用い る手法と距離情報を用いる手法に大別することができる。

オプティカルフローに基づく手法 ${ }^{(6)}$ (10) $は$ は, 静止物体領 域のオプティカルフローが，消失点を中心として放射状に 分布する性質を利用して, 弚の性質を満足しない領域を動 物体として検出したり，フローベクトルのクラスタリング によって対象を区別するなどの方法が採られている。これ らの提案により，多くの問題が解決された。しかしながら， 原理的に対象が観測系の光軸に平行な運動した場合, フロー ベクトルが十分に検出されず，しかも消失点の位置の差が 小さい場合には背景と動物体とを区別することが困難であ るいった問題がある。

距離画像を用いた手法 ${ }^{(11) \sim(13)}$ として , 物体の動き推定 ${ }^{(11)}$ 
を目的とした手法が多く提案されている。広範囲の距離情 報を用いた手法として，広範囲をスキャン可能なレーザー レンジファインダを用いた手法 ${ }^{(12)}$ では, 平面上のレーザ 走査により得られる正確な距離情報から動物体を検出して いるが , 水平 1 ラインの情報しか得られないため，一定の 高さにある動物体しか検出できない。また，レーザを回転 し走査するため，完全に同時刻の情報を取得できない。全 方位カメラを搭載した複数のロボットを用いた手法 ${ }^{(13)}$ で は，背景差分により得られる動物体領域に対し，ロボット 間のステレオ情報により光の3 次元位置を検出しているが， 動物体領域の検出に背景差分を用いているため，検出時に はロボットが静止する必要があり，時間的変化の大きい環 境では適応が難しい。

我々は，これまでに全方向ステレオシステム (Stereo Omni-directional System : 以下 SOS ) ${ }^{(17)}$ を提案してき た。3眼ステレオユニットを基本とするマルチカメラシス テムである SOS は，センサを中心とした全方向の高解像度 のカラー画像と隱蔽の少ない密な距離画像がリアルタイム に得られる。こうした性質を利用して，観測系の任意の平 行移動（垂直軸まわりの回転も含む）と，検出対象となる動 物体の任意の並進に対してロバストに動物体を検出するた めの手法を提案する。弚こで本手法ではまず，全方向距離 情報とカメラの自己運動パラメータから，観測系の前時刻 の全方向距離情報から現時刻の全方向距離情報を予測する。 そして予測された全方向距離情報と実際に観測された全方 向距離情報を比較することにより，動物体を検出すること を特徵とする。なお，一般の視野の限定されたカメラシス テムにおいては，前時刻の視野と現時刻の視野のオーバー ラップする範囲が十分でない場合があるが，SOS のように 全方位の視野をもつセンサーではオーバーラップ領域が十 分に得られ，比較が可能である。検出結果には観測系の移 動によって起こるオクルージョン領域が含まれるが，これ をあらかじめ予測することで検出結果から除去する。本手 法では，個別の特徵点や線分などを用いる手法と比較して， 領域全体を検出対象とすることにより，ノイズ等に対して 安定に対象を検出する。

本論文の構成は次のようである。2.では, 全方向ステレ オシステム (SOS) の概要について述べる。3.では，本手 法を構成する, 自己位置・姿勢推定と予測距離画像の算出 , およびオクルージョン領域の推定と差分領域の抽出法につ いて述べる。4.では，実画像を用いた実験により本手法の 有効性を示し，最後に本論文をまとめる。

\section{2. 全方向ステレオシステム (SOS)}

全方向ステレオシステム (SOS) は , システムを中心と した死角のない完全に全方向のカラー画像と距離情報をリ アルタイムに取得可能なシステムである ${ }^{(17)}$ 。図 1 に本シ ステムの外観を示す。本システムは，正 20 面体の各面上 に3眼ステレオユニットを配置した構造により，全方向に 対して等しく，高解像度な情報が得られる。カメラを $\mathrm{L}$ 字

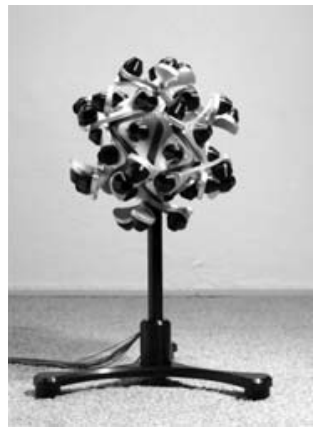

図 1 全方向ステレオシステム $(\mathrm{SOS})$ の外観

Fig. 1. The SOS prototype.

表 1 システムの仕樣

Table 1. SOS specifications.

\begin{tabular}{c|c}
\hline Image Sensor & $1 / 3^{\prime}$ CMOS Color Image Sensor \\
\hline Effective Resolution & $640(\mathrm{H}) \times 480(\mathrm{~V})$ \\
\hline Focal Length & $2.9 \mathrm{~mm}$ \\
\hline Field of View & $96.6 \mathrm{deg}(\mathrm{H}) \times 71.9 \mathrm{deg}(\mathrm{V})$ \\
\hline Baseline Length & $90 \mathrm{~mm}$ \\
\hline Diameter & $27 \mathrm{~cm}$ \\
\hline Weight & $4.5 \mathrm{~kg}$ \\
\hline
\end{tabular}

型アームにマウントした 3 眼ステレオユニットを用いるこ とにより, エピポーラ線に平行なエッジ特徵に対し距離が 計測できない 2 眼ステレオに対して，あらゆる方向のエッ ジ特徵に対し距離計測可能である。また , 2 組のステレオ ペアに対してエピポーラ拘束が利用できることから， 2 眼 ステレオと比較し信頼度が高く，隱蔽の少ない密な距離情 報を得ることができる。ダウンサイジングを図るために，3 眼ステレオユニットの配置を工夫することで, セルフ・オ クルージョンが発生しない限界のサイズにまで小型化され ている。表 1 にシステムの仕樣を示す。

\section{3. 全方向動き補償型距離差分法}

本論文で提案する全方向動き補償型距離差分法は，時刻 $t-\Delta t$ の時点の距離画像に基づいて予測された時刻 $t$ にお ける予測距離画像と，時刻 $t$ において実測された距離画像 を比較することで，動物体を検出することを基本とする。 以下で, 観測系の自己運動パラメータ算出方法, 予測距離 画像の算出法 , オクルージョン領域の推定法 , 光して差分 領域の抽出法について光れ艺れ述べる。

〈3. 1 1 観測系の自己運動パラメータの算出 時刻 $t-\Delta t$ から時刻 $t$ までの観測系 (SOS) の自己運動パラメー タである移動方向, 回転角度, 移動距離の算出を行う。ま ず，これまで我々が提案した全方位画像のエッジヒストグ ラムを用いた SOS の自己位置・姿勢 (水平回転) 推定手 法 ${ }^{(18)}$ によりSOS の移動方向，回転方向を決定し，次に， 時刻 $t-\Delta t$ および時刻 $t$ における全方向距離ヒストグラム に基づいて移動距離を求める，という手順で自己運動パラ メータを算出する。

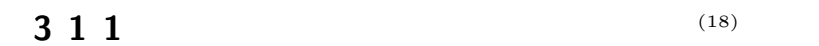




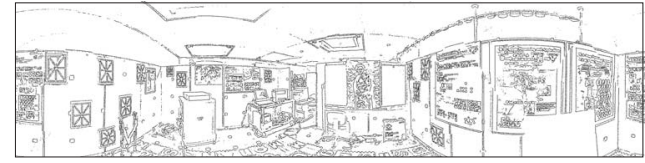

(a) panoramic edge image

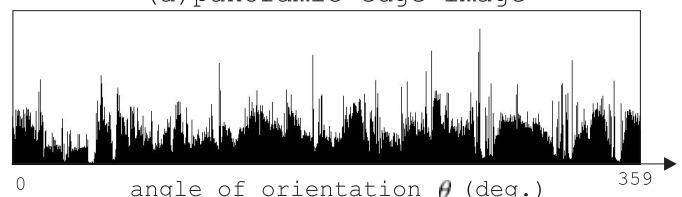

(b) edge histogram

図 2 エッジヒストグラムとパノラマ画像の一例

Fig. 2. An example of edge histogram and panoramic edge image.

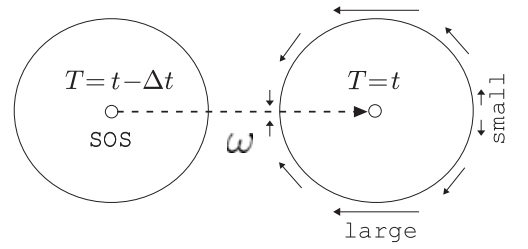

図 3 SOS の移動とエッジヒストグラムのシフト

Fig. 3. SOS movement and edge histogram shift.

りここでは光の概要について述べる。まず，SOS の全 方向画像から图 2(a) のような全方位エッジ画像を生成し， さらに各エッジ画素を垂直に投影したエッジヒストグラム を生成する (図 2(b))。この全方位エッジヒストグラムは 各方位のエッジ特徵を表しているため, SOS の移動や回 転運動により，各方位角においてヒストグラムのシフトを 引き起こす。回転運動では，すべての方位角において一定 にエッジが変化するため，ヒストグラムのシフト量は一定 である。一方，平行移動では，移動方向とエッジ方位角に 関係したシフト量が生じる。図 3 に示すように，SOS が 時刻 $t-\Delta t$ の地点からある方向 $\omega に$ 向いて動いたとき， $\omega \pm n \pi, n=0,1$ の方位角においてはヒストグラムのシフ 卜量が小さく, $\omega \pm \frac{(2 n+1)}{2} \pi, n=0,1$ の方位角においては そのヒストグラムのシフト量が大きくなる。これらのシフ 卜量は $\sin$ 曲線と同じ 周期性を持ち, SOS の回転運動は全 体的なシフト量に，移動方向は $\sin$ 曲線のゼロ位相に対応 する。これにより，時刻 $t-\Delta t$ における全方位エッジヒス トグラムと時刻 $t$ における全方位エッジヒストグラムを動 的計画法 (DP) を用いてマッチングし，各方位角における ヒストグラムのシフト量を求め, これらのシフト量から全 体のシフト量と关の周期のゼ口位相を独立に当てはめるこ とで, センサの移動方向 $\omega$ と回転角度 $\phi$ を効率的に推定す る。本稿では，時刻 $t-\Delta t$ における全方位エッジヒストグ ラムと時刻 $t$ における全方位エッジヒストグラムから，セ ンサの移動方向 $\omega$ と回転角度 $\phi$ を求めた。

〈3.1.2〉自己運動パラメータの算出 上述の手法か ら $\operatorname{SOS}$ の移動方向 $\omega$ と回転角度 $\phi$ が得られる。これらの 值から, 全方向距離画像を用いて, 移動距離 $l$ を求める。図 4 (a) は，実験環境の SOS の時刻 $t-\Delta t$ で得られた全方向 距離画像を床面に対し正射影し生成した全方向ヒストグラ

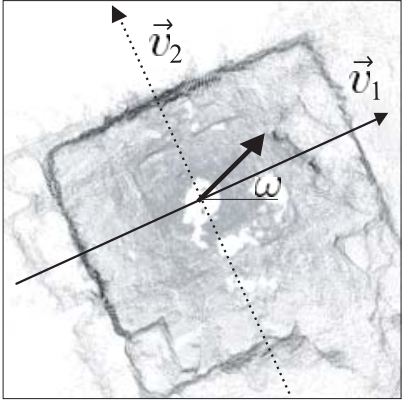

(a) distance histogram

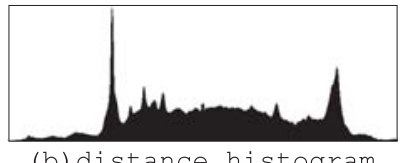

(b) distance histogram of $\mathrm{V} 1(T=t-\Delta t)$

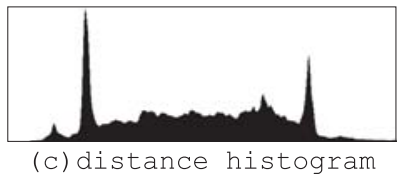
of $\mathrm{V} 1(T=t)$
Fig. 4. Exact position of SOS.

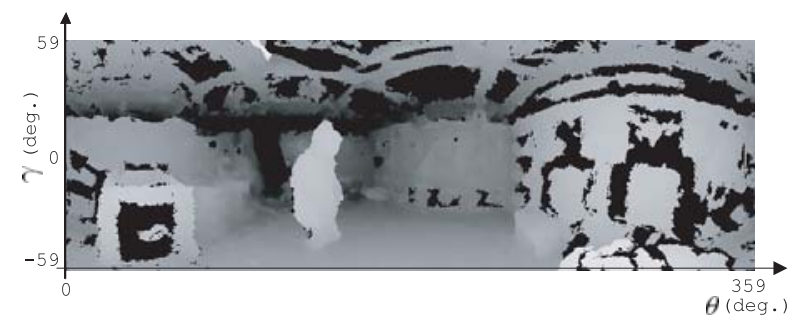

図 5 全方向ステレオ距離画像

Fig. 5. Omni-directional depth image.

ムであり, 壁部分が直線状のピークとして表れていること がわかる。このヒストグラムにおける直線までの距離変化 量を用いて移動方向 $\omega$ に対する移動距離 $l$ を推定する。ま ず, この全方向ヒストグラムにおける 2 次元座標点に対し て, 各点のヒストグラム值を重みとして考慮した Hough 変 換を行い，ヒストグラムにおける主な直線を検出する。こ れらの直線に対する距離変化を見るため, 全方向距離ヒス トグラムをさらに各直線に垂直な方向（ドミナント投影方 向 $\left.\vec{v}_{1}, \vec{v}_{2}\right)$ に投影した距離ヒストグラムを生成する。移動 方向 $\omega$ に最も近いドミナント投影方向 (図 4 では $\vec{v}_{1}$ ) にお ける時刻 $t-\Delta t$ と時刻 $t$ の距離ヒストグラム (弚れ光れ図 4(b),(c)) をマッチングすることにより $\operatorname{SOS}$ の移動距離 $l$ を 求める。

〈3.2〉 全方向予測距離画像の算出 時刻 $t-\Delta t$ に取得 した全方向距離画像と前節で推定した SOS の自己運動パラ メータから, 時刻 $t$ の時点で得られる全方向距離画像を推定 する。SOSの各ステレオユニットにより得られた距離画像を 各ユニットの配置パラメータを用いて球面座標系で表現し， 統合することにより全方向距離画像を生成する。図 5 に生 成した全方向距離画像の例を示す。ここで横軸は方位角 $(\theta)$ であり，絴軸は仰角 $(\gamma)$ である。 $0<\theta<2 \pi,-\frac{\pi}{3}<\gamma<\frac{\pi}{3}$ の範囲を対象とする。時刻 $t-\Delta t$ の全方向距離画像の方位 角 $\theta$, 仰角 $\gamma$ 方向における距離值 $s_{\theta, \gamma}$ の画素は, $\langle 3 \cdot 1\rangle$ 節に よって得られた時刻 $t$ までの自己運動パラメータ $(\operatorname{SOS} の$ 回転 $\phi$, 移動方向 $\omega$ と炎の移動距離 $l)$ により, 方位角 $\theta^{\prime}$, 仰角 $\gamma^{\prime}$ 方向の距離値 $p_{\theta^{\prime}, \gamma^{\prime}}$ の点に移動する。 $\theta^{\prime}, \gamma^{\prime}, p_{\theta^{\prime}, \gamma^{\prime}}$ は $\operatorname{SOS}$ の回転 $\phi$, 移動方向 $\omega$ と光の移動距離 $l$ を用いて次の ように求めることができる (付録 1 . 参照)。

$$
d^{\prime}=\sqrt{s_{\theta, \gamma}^{2}+l^{2}-2 s_{\theta, \gamma} l \cos (\theta-\omega) \cos \gamma} \cdots \cdots
$$




$$
\begin{gathered}
\gamma^{\prime}=\arcsin \left(\frac{s_{\theta, \gamma} \sin \gamma}{d^{\prime}}\right) \ldots \ldots \ldots \ldots \ldots \\
\theta^{\prime}=\left\{\begin{array}{c}
\arccos \left(\frac{s_{\theta, \gamma} \cos \theta \cos \gamma-l \cos \omega}{d^{\prime} \cos \gamma^{\prime}}\right)-\phi \\
i f\left(s_{\theta, \gamma} \sin \theta \cos \gamma-l \sin \omega \geq 0\right) \\
2 \pi-\arccos \left(\frac{s_{\theta, \gamma} \cos \theta \cos \gamma-l \cos \omega}{d^{\prime} \cos \gamma^{\prime}}\right)-\phi \\
\text { otherwise }
\end{array}\right.
\end{gathered}
$$

$p_{\theta^{\prime}, \gamma^{\prime}}=d^{\prime}$

これにより時刻 $t-\Delta t$ における全方向距離画像から，時刻 $t$ における全方向距離画像を推定する。

〈3. 3〉 オクルージョン領域の推定 〈3・2 節より環境 の 3 次元変化は推定できるが , 観測系の移動によって新た に見える領域 (オクルージョン領域) は推定することができ ない。光のため，この予測画像と時刻 $t$ において実測され た距離画像の差分をとった画像には，このオクルージョン 領域も含まれる。観測系が移動することによって生じる才 クルージョン領域を推定する。オクルージョンは環境にお ける物体とカメラの位置関係と, カメラの移動量とに深く 関係し，奥行きが急激に変化する部分 (ジャンプエッジ)に 生じる。透視射影画像におけるオクルージョンについては， モデル生成に関する文献 ${ }^{(14) \sim(16)}$ においてよく解析されてい るが，ここでは SOS の全方向画像を表す球面座標系 $(\theta, \gamma)$ におけるオクルージョン領域の計算法について述べる。

図 6 に示すように, $\operatorname{SOS}$ が点 $S$ から点 $T$ へ移ったとき， 点 $S$ の球面画像における各画素 $P=(\theta, \gamma)$ は, $\operatorname{SOS}$ の移 動方向 $\omega$ で決められる方向 $\vec{v}=\left(v_{\theta}, v_{\gamma}\right)$ に沿って，点 $T$ で は $P^{\prime}$ へ移動する。 $\vec{v}$ は式 $(5),(6),(7)$ によって計算でき る (付録 2. 参照)。

$$
\begin{aligned}
& v_{\theta}=\operatorname{farctan}\left(\frac{(\sin \omega+\cos \theta \sin (\theta-\omega)) \cos ^{2} \gamma-\sin \omega}{(\cos \omega-\sin \theta \sin (\theta-\omega)) \cos ^{2} \gamma-\cos \omega}\right) \\
& \ldots \ldots \ldots \ldots \ldots \ldots(5) \\
& f=\left\{\begin{aligned}
-1 & \text { if }(\cos (\theta-\omega) \geq 0) \\
1 & \text { otherwise }
\end{aligned}\right. \\
& v_{\gamma}=\arcsin (\cos (\theta-\omega) \sin \gamma \cos \gamma) \cdot
\end{aligned}
$$

図 6 に示すように，画素 $P$ の移動方向と逆方向 $-\vec{v}$, 奥 行きが小さい值から大きい值に変化するジャンプエッジ (図 6 では $A$ ) においてオクルージョンが生じる。ここで，注 目画素 $P$ の距離値 $s_{\theta, \gamma}$ に対して $-\vec{v}$ 方向で隣り合う画素 $P_{N}=P-\vec{v}=\left(\theta-v_{\theta}, \gamma-v_{\gamma}\right)$ の距離値 $s_{\theta-v_{\theta}, \gamma-v_{\gamma}}$ が式 (8) を満たせば，画素 $P$ においてオクルージョンが発生す ると判断する。ここで, $\vec{v}=\left(v_{\theta}, v_{\gamma}\right)$ は， $\vec{v}=\left(v_{\theta}, v_{\gamma}\right)$ を 8 近傍に離散化したものである。

$$
s_{\theta-v_{\theta}, \gamma-v_{\gamma}}-s_{\theta, \gamma}>T_{d}
$$

ここで， $T_{d}$ は奥行き変化に対する閾値であり，実験では $T_{d}=15(\mathrm{~cm})$ とした。

式 (8) を満たす場合，SOS が移動することにより，画素 $P$ と $P_{N}$ が移った画素 $P^{\prime}$ と $P_{N}^{\prime}$ の間に幅 $W$ のオクルー

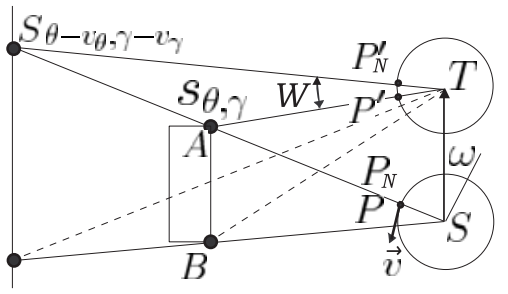

図 6 オクルージョン領域の算出

Fig. 6. Calculation of occluded regions.

ジョンが生じる。このオクルージョンの幅 $W$ は, 式 $(9)$, (10) (付録 3. 参照) で計算でき, 予測画像において生じるオ クルージョン領域 $O_{\theta, \gamma}$ は画素 $P^{\prime}$ と $P_{N}^{\prime}$ 間として式 $(12)$, (11) によって与えられる (図 6)。

$$
\left.\begin{array}{c}
\alpha(\theta, \gamma, d)=\arccos \left(\frac{d \cos (\theta-\omega) \cos \gamma-l}{\sqrt{d^{2}+l^{2}-2 d l \cos (\theta-\omega) \cos \gamma}}\right) \\
\ldots \ldots \ldots \ldots \ldots \ldots \ldots(9)
\end{array}\right)
$$

ここで，画素 $P$ と $P_{N}$ の方位角，仰角，距離值を嘸れぞ れ $\theta_{1}, \gamma_{1}, d_{1}$ と $\theta_{2}, \gamma_{2}, d_{2}$ である。一方，図 6 中の $B$ の位 置では, $-\vec{v}$ の方向に, シーンの奥行きが大きい值から小 さい值に変化するジャンプエッジが存在するが , このよう な場合は予測画像において手前の物体にオーバーラップさ れるため，考慮する必要はない。

〈3. 4 〉 動物体領域の抽出 $\langle 3 \cdot 2\rangle$ 節で得られた予測距 離画像と, 時刻 $t$ において実測される距離画像から差分画 像を生成する。時刻 $t$ に取得した全方向距離画像の距離値 を $g_{\theta, \gamma}$, 生成した予測画像の距離値を $p_{\theta, \gamma}$ とすると，求め る差分画像の距離差分値は $\delta_{\theta, \gamma}$ は,

$$
\delta_{\theta, \gamma}=g_{\theta, \gamma}-p_{\theta, \gamma}
$$

で表される。この值に対し次の 3 值化を施す。

$$
d_{\theta, \gamma}=\left\{\begin{aligned}
-1 & \text { if }\left(\delta_{\theta, \gamma}<-T_{\delta}, O_{\theta, \gamma}=0\right) \\
1 & \text { if }\left(\delta_{\theta, \gamma}>T_{\delta}, O_{\theta, \gamma}=0\right) \\
0 & \text { otherwise }
\end{aligned}\right.
$$

ここで， $T_{\delta}$ は予測画像での距離値と時刻 $t$ での距離值の差 に対する閾値 (検出閾値) であり，実験では $T_{\delta}=15(\mathrm{~cm})$ とした。この式により, SOS に近い位置へ変化した領域は 正の值として，遠ざかった領域は負の值として表現される。

この検出結果には, オクルージョンによる変化領域も含 まれるので， $\langle 3 \cdot 3\rangle$ 節にて推定したオクルージョン領域を除 外する。更に，面積フィルタによるノイズ除去処理を施し， 動物体候補領域を抽出する。なお, 動物体の移動量が小さ い場合，検出結果に現れる領域も小さなものとなることや， 
SOS から対象までの距離により画像における対象領域面積 が変化することから，一定の閾值で動物体とノイズと区別 することが難しい。乥こで, 対象の検出すべき最小移動距離 $l_{m}$ ，対象とする移動物体の大きさ (幅 $w \times$ 高さ $h$ ) , SOS から対象領域までの距離 $R_{m}$ を用いて，本稿では，検出対 象は床上を移動するものとし，面積フィルタの閾值を式 15 のようにした。

$$
\begin{aligned}
S_{t h}= & \frac{2}{r e s^{2}} \arctan \left(\frac{l_{m}}{2 R_{m}}\right)\left(\arctan \left(\frac{h-h_{\text {sos }}}{R_{m}}\right)\right. \\
& \left.+\arctan \left(\frac{h_{\text {sos }}}{R_{m}}\right)\right) \ldots \ldots \ldots \ldots \ldots \ldots \ldots
\end{aligned}
$$

ここで,res は方位角と仰角の分解能, $h_{\text {sos }}$ は床から SOS までの高さである。 $l_{m}$ の範囲は $0<l_{m}<w$ である。対 象までの距離が大きいとき，画像上に現れる領域は小さく なるが，ここでは各領域までの距離 $R_{m}$ を考慮することで， 対象までの距離に関係なく $l_{m}$ 以上移動する動物体を検出す る。なお, $l_{m}$ が小さい場合，時刻 $t-\Delta t$ および時刻 $t$ にお ける動物体領域は，大部分が重なるため，動物体領域全体で はなく変化があった部分のみが検出される。固定カメラシ ステムでよく用いられるフレーム間差分法のようにこの情 報を用いた処理も検討できるが，本論文では行っていない。 次章以降の実験においては, 分解能 res を $2.0, \mathrm{SOS}$ の高さ $h_{\text {sos }}$ を $150 \mathrm{~cm}$ ，対象とする動物体を人物 (幅 $(w) 30 \mathrm{~cm} \times$ 高さ $(h) 160 \mathrm{~cm})$ ，検出範囲を $3 \mathrm{~m}$ まで，対象動物体の最小 移動距離 $l_{m}$ を $30 \mathrm{~cm}$ とし, 動物体 (人物) 全体の領域が 検出されるようにした。

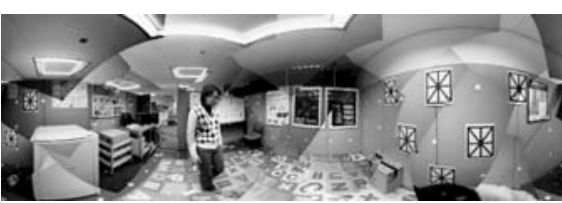

(a) color image $(T=t-\Delta t)$

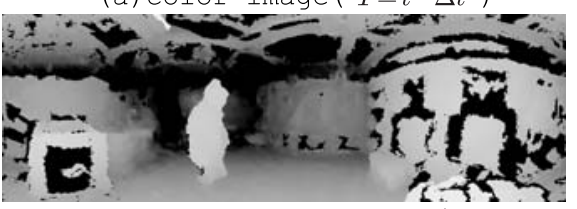

(b) depth image $(T=t-\Delta t)$

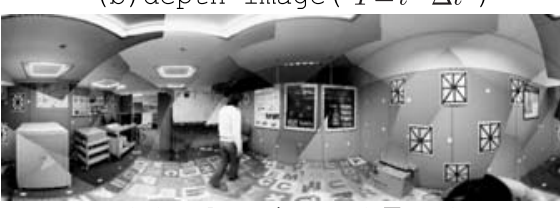

(c) color image $(T=t)$

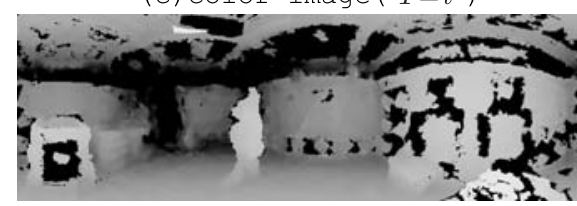

(d) depth image $(T=t)$

图 7 時刻 $t-\Delta t$ および時刻時刻 $t$ における全方 向カラー画像および全方向距離画像

Fig. 7. Omni-directional color and depth images for time $t-\Delta t$ and time $t$.

\section{4. 実験}

本手法の有効性を検証するため，実画像を用い実験を行っ た。図 7(a),(b) および図 7(c),(d) は，光れぞれ SOS にから 取得した時刻 $t-\Delta t$ および時刻 $t$ における全方向カラー画像 および全方向距離画像である。時刻 $t-\Delta t$ から時刻 $t$ にかけ て，SOS および人物の弚れ光れが移動していることがわか る。ここで SOS の自己運動パラメータは，〈3・1 節で述べた 方法により $l=27.69(\mathrm{~cm}), \omega=3.26(\mathrm{rad}), \phi=0.10(\mathrm{rad})$ を得た。この相対移動量と，時刻 $t-\Delta t$ における距離情 報 (図 7(b)) を用いて生成した時刻 $t$ の予測距離画像を図 8(a)に示す。

図 8(b) は，図 8(a)の予測距離画像と時刻 $t$ において実 測した距離画像（図 $7(\mathrm{~d})$ ) との差分をとり，差分值が正の 領域を白で，負の領域をグレーで示したものである。ここ で, グレーで示す領域は時刻 $t-\Delta t$ から時刻 $t$ にかけて消
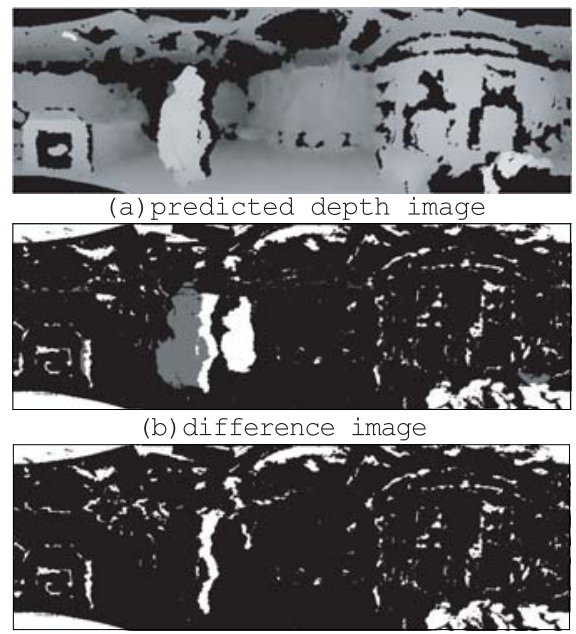

(c) presumed occluded regions

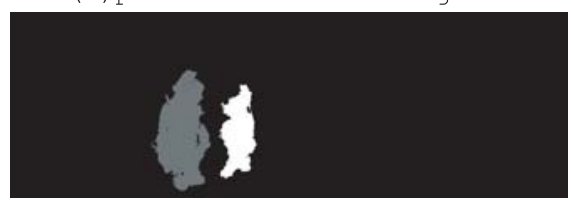

(d) detected regions

図 8 実験結果

Fig. 8. Experiment results.

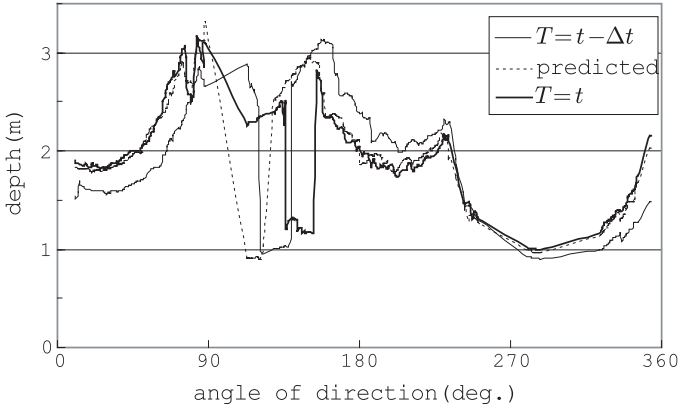

図 9 時刻 $t-\Delta t$, 時刻 $t$ での距離画像, 予測距 離画像の距离隹值

Fig. 9. Depth values of depth images for time $t-\Delta t$ and time $t$, and the predicted depth image. 


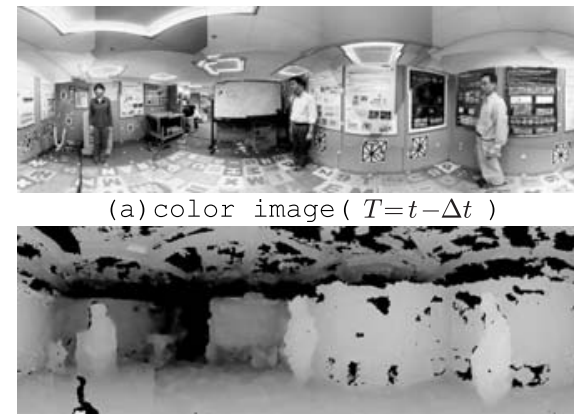

(b) depth image ( $T=t-\Delta t)$

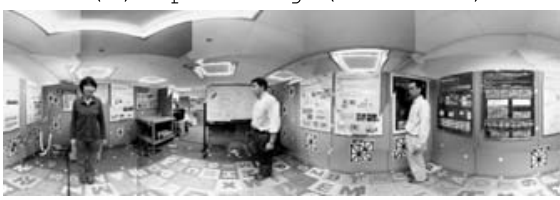

(c) color image ( $T=t$

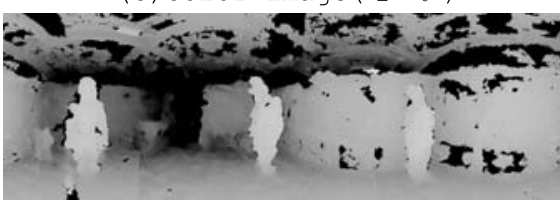

(d) depth image ( $T=t)$

図 10 入力画像

Fig. 10. Input images.

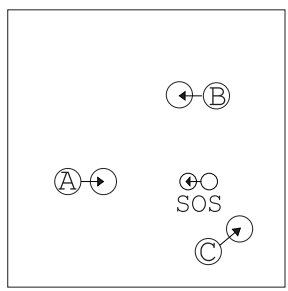

図 11 実験条件

Fig. 11. Experiment conditions.

失した物体の領域の候補，白で示す領域は出現した物体の 領域の候補を乥れ示す。白で示す領域には，才クルー ジョン領域も候補として検出されているが， $\langle 3 \cdot 3\rangle$ 節で述 ベた方法に従ってオクルージョン領域を推定し (8(c)) 除去 した後，面積フィルタによるノイズ除去処理を施し，候補 領域を取り出したものを図 8(d) に示す。観測系が移動し ているにもかかわらず，動物体である人物領域を安定にひ とつの領域として検出できている。図 9 に時刻 $t-\Delta t$ (図 $7(\mathrm{~b}))$ ，時刻 $t$ (図 7(d))，予測 (図 8(a)) の各距離画像の上 端から 120 ピクセル目の水平 1 ラインの距離值をプロッ卜 したグラフを示す。このグラフから，動物体が存在しない 領域では，予測距離值と実測距離值がよく一致しているこ とがわかる。一方で, 動物体が存在する領域においては大 きな差違を生じている。このことから，乥れ光れの領域は 十分判別可能であり，提案したアルゴリズムが良好に機能 していることがわかる。

次に複数の人物が存在する環境において実験を行った。 図 10 に，SOSによって取得した画像群を示す。図10(a)中

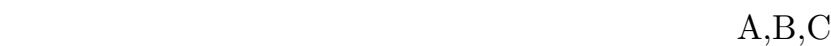
と呼ぶ。図 11 に, SOS および光れ尓れの人物の位置関係
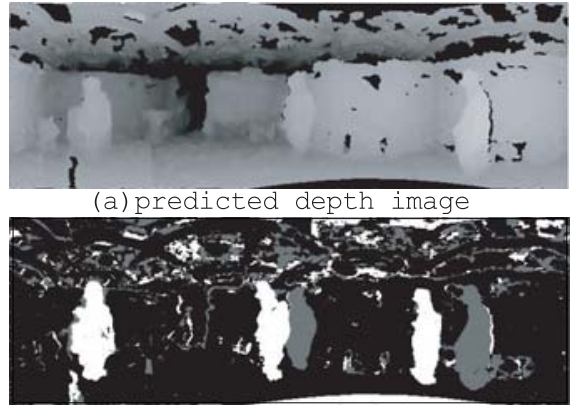

(b) difference image

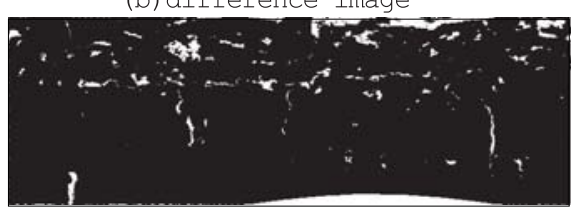

(c) presumed occluded regions

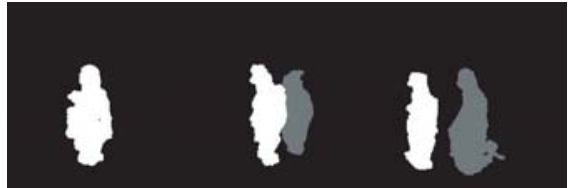

(d) detected regions

図 12 実験結果

Fig. 12. Experiment results.

と移動状態を示す。人物 A は, SOS の進行方向と同一直線 上を SOS に向かって移動する。人物 B は，併走するよう に SOS の進行方向と平行に移動する。人物 C は， SOS の 後方をSOS の進行方向に対して斜めに進行する。

これまでの手順と同樣に，SOS の自己運動パラメータ $l=13.0(\mathrm{~cm}), \omega=0.90(\mathrm{rad}), \phi=-0.03(\mathrm{rad})$ を算出し 図 12 に示す検出結果を得た。図 $12(\mathrm{~d})$ を見ると，検出対 象である 3 人の人物領域を安定に検出できている。ここで， 人物 A は SOS の進行方向線上を移動しており，これまで に提案されてきたオプティカルフローに基づく方法におい ては検出が困難とされていたが , 本手法においては, 他の 移動パターンと同じく検出が可能であることがわかる。次 に距離情報の精度が検出へ及ぼす影響について考察する。 本手法の検出能力は SOS によって得られる距離情報の精度 に依存する。距離の誤差としては，理論的に対象までの奥 行きの 2 乗に比例した奥行き誤差が生じるほかに，SOSで はパッシブステレオを採用しているため，ステレオ対応点 探索精度が環境のテクスチャに依存する。このため一概に は論じることが出来ないが，今回実験を行った環境におい ては, $2 \mathrm{~m}$ の距離において $\pm 5,6 \mathrm{~cm}$ 程度の誤差を観測した。 このことから，例えば人物が壁に沿って移動する場合にお いても，通常人間の幅は $20 \mathrm{~cm}$ 以上あるため検出が可能で あることがわかる。一方，図 10 の人物 A のように SOS の 進行方向線上を運動する場合には，壁ではなく， $\Delta t$ 時間前 の人物位置との比較になるため, 距離の誤差より大きな人 物の移動量が必要になる。

5. むすび

全方向ステレオシステム $(\mathrm{SOS})$ を用いて SOS 自身が移 
動しながら動物体を検出するための手法を提案した。SOS から得られる隠蔽の少ない密な全方向距離情報と SOS の 全方向画像から得られる自己運動パラメータを用いて，時 刻 $t-\delta t$ の距離画像から時刻 $t$ の距離画像を予測し，時刻 $\mathrm{t}$ の実測距離画像と比較することで環境中の動物体を領域と して安定に検出した。また，視点の移動によって生じるオ クルージョン領域を距離画像のジャンプエッジに注目し推 定することで, 検出結果への影響を低減した。今後は, 検 出された動物体領域から得られる属性, 3 次元的移動量 (方 向性と移動量) の評価，また，おかれた環境や動物体の位 置や動きの情報に基づいた，SOS の適応的な移動制御（移 動方向や速度等) について考えていく。

\section{謝 辞}

本研究を進めるにあたり有益なご意見を頂いた，名古屋 工業大学電気情報工学科, 佐藤淳助教授に深く感謝いたし ます。

(平成 15 年 7 月 14 日受付，平成 15 年 11 月 10 日再受付)

\section{文献}

( 1 ) V.L. Lumelsky: "Path-Planning Strategies for a Point Mobile Automation Moving Admist Unkown Obstacles of Arbitrary Shape", Algothmica, Vol.2, pp.403-430 (xxxx)

( 2 ) Charies W. Warren: "Multiple robot path coordinations using artifical fields", In Proc. the 1990 IEEE International Conf. on Robotics and Automation, pp.500-505 (1990)

( 3 ) T. Tsubouchi,K.Hiraoka, T. Naniwa, and S. Arimoto, "A mobile robot navigation scheme for an environment with multiple moving obstacles", In Proc. the 1992 IEEE/RSJ International Conf. of Intelligent Robots and Systems, pp.1791-1798 (1992)

(4) S. Ishikawa and S. Asaka: "A Method of Piloting an Autonomous Mobile Robot in Dynamically Changing Environment Including Moving Obstacles", JRSJ, Vol.11, No.6, pp.856-867 (1993-6) (in Japanese)

石川繁樹・浅香俊一:「移動障害物を含むような動的変化を伴う走行 環境における自律移動ロボットの走行誘導方式」, 日本ロボット学 誌学術論文 , 11, 6, pp.856-867 (1993-6)

( 5 ) N. Inoue, K. Inoue, and Y. Ookawa: "On-line Motion Planning of an Autonomous Mobile Robot to Avoid Multiple Moving Obstacles Based on the Prediction of Their Future Trajectories", JRSJ, Vol.15, No.2, pp.249-260 (1997-2) (in Japanese)

井上 晃・井上健司・大川善邦: 「複数移動障害物の行動予測に基つ く自律移動ロボットのオンライン回避行動」, 日本ロボット学誌学 術論文 , 15, 2, pp.249-260 (1997-2)

(6) J. Frazier and R. Nevatia: "Detecting moveing objects from moving platform", Proc. 1992 IEEE Int. Conf. on Robotics and Automation, pp.1627-1633 (1992)

( 7 ) N. Ohta: "Structure from motion with confidence measure and its application for object detection", IEICE Trans. Vol.76-D-II, No.8, pp.1562-1571 (1993-8) (in Japanese) 太田直哉 : $\ulcorner$ 信頼性情報をもつたオプティカルフローからの形状復 元と光の移動物体検出への応用」, 信学論 (D-II), J76-D-II，8, pp.1562-1571 (1993-8)

( 8 ) M. Watanabe, N. Takeda, and K. Onoguchi: "A Moving Object Recognition Method by the Principal Component Analysis", IPSJ SIGNotes Computer Vision No.099 (1995) (in Japanese)

渡辺 睦・武田信之・小野口一則 :「主成分分析を用いた移動物体 認識法の検討」, 情報処理論学会, 研究報告コンピュータビジョン No.099 (1995)

(9) A. Nagai, Y. Kuno, and Y. Shirai: "Detection of moving objects in changeing background", IEICE Trans., Vol.J80-D-II, No.5, pp.1086-1095 (1997-5) (in Japanese)

長井 敦・久野義德・白井良明 :「複杂杂変動背景下における移動物体
の検出」, 信学論 (D-II), J80-D-II, 5, pp.1086-1095 (1997-5)

(10) T. Ebine and N. Hamada: "Detection of Moving Objects Using Observer Motion-based Optical Flow Estimation", IEICE Trans., Vol.J83-D-II, No.6, pp.1498-1506 (2000-6) (in Japanese)

海老根 巧・浜田 望 : 「観測系の運動を考慮したオプティカルフ ロー推定に基づく運動物体検出」, 信学論 (D-II), J83-D-II, 6, pp.1498-1506 (2000-6)

(11) B. Sabata and J.K. Aggarwl: "Estimation of Motion from a Pair of Range Images: A Review", CVGIP(54), No.3, pp.309324 (1991-11)

(12) M. Lindström and J.-O.Eklundh: "Detecting and Tracking Moving Objects from a Mobile Plateform using a Laser Scanner", Proc. IEEE Int. Conf. on Intelligent Autonomous System, pp.620-627 (2000)

(13) Z. Zhu, K.D. Rajasekar, E.M. Riseman, and A.R. Hanson: "3D Localization of Multiple Moving People by an Omnidirectional Stereo System of Cooperative Mobile Robots", UMass CS TR 2000-14 (2000-3)

(14) J. Maver and R. Bajcsy: "Occlusion as a Guide for Planning the Next View", IEEE Trans. PAMI, Vol.15, No.5, pp.417-33 (1993)

(15) W.R. Mark, L. McMillan, and G. Bishop: "Post-rendering 3D warping", Proc. 1997 Syposium on Interactive 3D Graphics, Providence, RI, pp.7-16 (1997-4)

(16) K. Hiruma, T. Okimura, and K. Uehira: "View Generation for a Virtial Camera Using the Multiple Depth Maps", IEICE Trans., Vol.J84-D-II, No.5, pp.805-811 (2001-5) (in Japanese) 昼間香織・沖村隆幸・上平員丈: 「複数の奥行きマップを用いた仮想視点 画像の生成」, 信学論 (D-II), J84-D-II, 5, pp.805-811 (2001-5)

(17) K. Yamamoto, H. Tanahashi, S. Kuwashima, and Y. Niwa: "Sensing of Real Environment by Stereo Ominiderectional System(SOS)", T.IEE Japan, Vol.121-C, No.5, pp.876-881 (2001-5) (in Japanese)

山本和彦・棚橋英樹·桑島茂純·丹羽義典: $\ulcorner$ 実環境センシングのための 全方向ステレオシステム (SOS)」, 電学論 C , 121, 5, pp.876-881 (2001-5)

(18) C. Wang, H. Tanahashi, Y. Sato, H. Hirayu, Y. Niwa, and K. Yamamoto: "Loaction and Pose Estimation for Active Vision Using Panoramic Edge Histograms", IEICE Trans., Vol.J86D-II, No.10, pp.1400-1410 (2003-10) (in Japanese) 王 彩華 - 棚橋英樹 - 佐藤雄隆 - 平湯秀和 - 丹羽義典 - 山本和彦 : 「全方位エッジヒストグラムを用いたセンサの位置・姿勢推定」, 信 学論 (D-II), J86-D-II, 10, pp.1400-1410 (2003-10)

付 録

\section{1. 予測画像の生成}

$\operatorname{SOS}$ の回転がなく $\omega$ 方向に距離lだけ移動した場合を考 える。全方向距離画像の画素 $P=(\theta, \gamma)$, 距離值 $d$ の三次元 座標は,,$(d \cos \theta \cos \gamma, d \sin \theta \cos \gamma, d \sin \gamma)$ であり, $\mathrm{SOS}$ の移 動により $(d \cos \theta \cos \gamma-l \cos \omega, d \sin \theta \cos \gamma-l \sin \omega, d \sin \gamma)$ へ移る。同樣に移動した画素 $P^{\prime}=\left(\theta^{\prime}, \gamma^{\prime}\right)$, 距離値 $d^{\prime}$ の 3 次元座標は $\left(d^{\prime} \cos \theta^{\prime} \cos \gamma^{\prime}, d^{\prime} \sin \theta^{\prime} \cos \gamma^{\prime}, d^{\prime} \sin \gamma^{\prime}\right)$ となり， 以下の式が成り立つ。

$$
\left\{\begin{array}{l}
d^{\prime} \cos \theta^{\prime} \cos \gamma^{\prime}=d \cos \theta \cos \gamma-l \cos \omega \\
\left.d^{\prime} \sin \theta^{\prime} \cos \gamma^{\prime}=d \sin \theta \cos \gamma-l \sin \omega \cdots \text { (付 } 1\right) \\
d^{\prime} \sin \gamma^{\prime}=d \sin \gamma
\end{array}\right.
$$

上式から $\theta^{\prime}, \gamma^{\prime}, d^{\prime}$ について解くことで，式 (1)，(2)，(3)， (4) が求められる。ここで, 画素 $P$ は, $\operatorname{SOS}$ の回転運動に 対し方位角方向へ回転角度 $-\phi$ 移るのみであるため， $\theta^{\prime}$ か らфを引く。

\section{2.オクルージョン方向の算出}

SOS の移動方向 $\omega$ により決められる画素 $P$ の移動方向 $\vec{v}=\left(v_{\theta}, v_{\gamma}\right)$ は, $\operatorname{SOS}$ 中心 $O$ を中心とする球面上画素 $P$ 


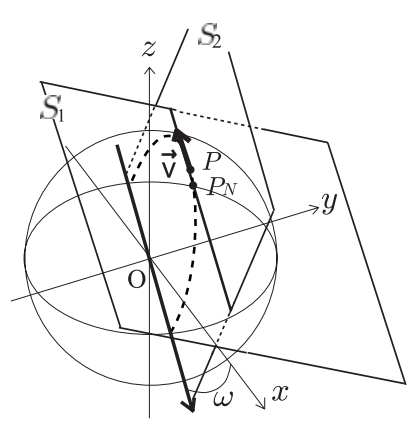

付図 1 オクルージョン方向の算出

app. Fig. 1. Calculation of occluded directions.

における接面 $S_{1}$ と $P, O$ を通り $\operatorname{SOS}$ の移動方向 $\omega$ を含 む平面 $S_{2}$ との交線方向となる。平面 $S_{1}$ の法線べクトル $\vec{n}_{1}=(\cos \theta \cos \gamma, \sin \theta \cos \gamma, \sin \gamma)$ と平面 $S_{2}$ の法線ベクト ル $\vec{n}_{2}=(-\sin \omega \sin \gamma, \cos \omega \sin \gamma,-\cos \gamma \sin (\theta-\omega))$ の交 線ベクトル $\vec{v}_{l}$ は以下のように得られる。

$$
\vec{v}_{l}=\left(\begin{array}{c}
(\cos \omega-\sin \theta \sin (\theta-\omega)) \cos ^{2} \gamma-\cos \omega \\
(\sin \omega+\cos \theta \sin (\theta-\omega)) \cos ^{2} \gamma-\sin \omega \\
\sin \gamma \cos \gamma \cos (\theta-\omega)
\end{array}\right)
$$

$\vec{v}_{l}$ は, $\vec{v}=\left(v_{\theta}, v_{\gamma}\right)$ を用いて $\vec{v}_{l}=\left(\cos _{\theta} \cos _{\gamma}, \operatorname{sinv}_{\theta} \cos v_{\gamma}\right.$, $\left.\operatorname{sinv} v_{\gamma}\right)$ と表されるため, 上式との関係より式 (5)，(6)，(7) が求められる。

\section{3. オクルージョン幅の算出}

予測画像においてオクルージョン領域は $P^{\prime}$ と $P_{N}^{\prime}$ の間 の領域，幅 $W$ は $P^{\prime}$ と $P_{N}^{\prime}$ のなす角として現れる。 $P^{\prime}$ と $P_{N}^{\prime}$ は, 画素 $P$ と SOS 中心 $O$ を通り, SOS の移動 方向 $\omega$ を含む平面 $S_{2}$ 上にある。平面 $S_{2}$ に対し，SOS の 3 次元移動方向 $(\cos \omega, \sin \omega, 0)$ を $x$ 軸とした 2 次元 座標系で考えると, $P^{\prime}\left(\cos \theta^{\prime} \cos \gamma^{\prime}, \sin \theta^{\prime} \cos \gamma^{\prime}, \sin \gamma^{\prime}\right)$ は， $\left(d \cos (\theta-\omega) \cos \gamma-l, d \sqrt{1-\cos ^{2} \gamma \cos ^{2}(\theta-\omega)}\right)$ となり， 移動方向 $\omega$ とのなす角 $\alpha(\theta, \gamma, d)$ は以下の式で得られる。

$$
\alpha(\theta, \gamma, d)=\arccos \left(\frac{d \cos (\theta-\omega) \cos \gamma-l}{\sqrt{d^{2}+l^{2}-2 d l \cos (\theta-\omega) \cos \gamma}}\right)
$$

$P, P_{N}$ の方位角，仰角，距離值を兰れ光れ $\theta_{1}, \gamma_{1}, d_{1}$ ，乥し て $\theta_{2}, \gamma_{2}, d_{2}$ とすると $P^{\prime}, P_{N}^{\prime}$ の $\mathrm{SOS}$ の移動方向 $\omega$ とのな す角は $\alpha\left(\theta_{1}, \gamma_{1}, d_{1}\right), \alpha\left(\theta_{2}, \gamma_{2}, d_{2}\right)$ となり，乥の差分が幅 $W$ となる。(式 (10))

清 水 早苗 (非会員) 1977 年 11 月 12 日生。 2000 年, 名

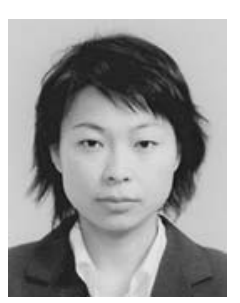
古屋大学情報文化学部自然情報学科卒業。2002 年, 同大大学院人間情報学研究科博士前期課程修 了。同年岐阜県 (生産情報技術研究所) 入庁。現 在 (財) ソフトピアジャパン地域結集型共同研究 推進室 (HOIP) 専門研究員。岐阜大大学院工学研 究科博士後期課程在学。

山 本 和 彦 (正員) 1944 年 6 月 20 日生。1971 年, 東京電大

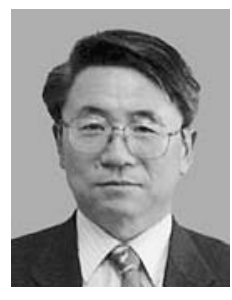
大学院修士課程了。同年電子技術総合研究所入所。 1979 年〜1980 年, 米国メリーランド大学にて並 列分散型画像理解の研究。1986 年〜1994 年, 電 子技術総合研究所知能情報部画像研究室室長。現 在 , 岐阜大学工学部応用情報学科教授。博士 ( 工 学)。人工知能, パターン認識, 特に図形の柔軟 な対応付けの研究に従事。

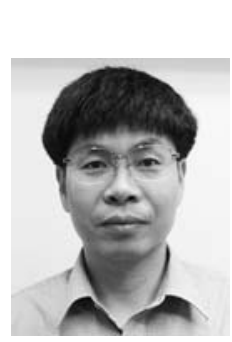

(非会員) 1963 年 8 月 26 日生。1983 年, 中国 人民大学情報工卒業。1986 年, 同大修士課程修 了。同大コンピュータセンター助手 , 1988 年講 師。1996 年静岡大学電子科学研究科博士課程修 了。同年科技団特別研究員として電総研で研究に 従事。現在 (財) ソフトピアジャパン地域結集型 共同研究推進室 (HOIP) 主任専門研究員。博士 (工学)。画像マッチング, ステレオ画像処理, 3 次元モデリングの研究に従事。情報処理学会会員。

佐 藤 雄 隆

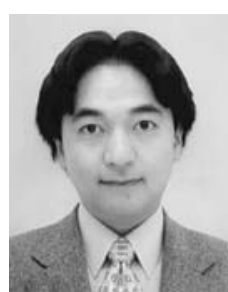

(非会員) 1971 年 5 月 13 日生。1996 年, 東京 農工大学工学部卒業。1998 年同大大学院博士前 期過程了。2001 年北海道大学大学院工学研究科 システム情報工学博士後期過程了。博士 (工学)。 現在 (財) ソフトピアジャパン地域結集型共同研 究推進室 (HOIP) 主任専門研究員。精密工学会, 映像情報メディア学会各会員。

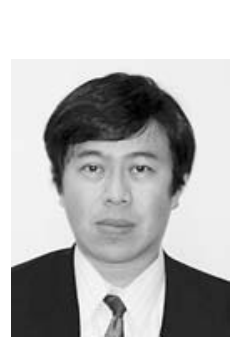

(非会員) 1963 年 9 月 15 日生。1985 年, 岐阜大 学電子工学科卒。同年岐阜県 (工業技術センター) 入庁。1998 年, 岐阜大学工学研究科博士課程了。 現在, 岐阜県生産情報技術研究所主任専門研究員。 博士 (工学)。コンピュータビジョン, 特に画像 からの 3 次元形状再構成と光の応用研究に従事。 電子情報通信学会, 人工知能学会各会員。

丹 羽 義 典

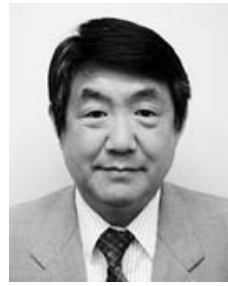

(非会員) 1951 年 10 月 23 日生。1974 年, 名 古屋大学工学部卒業。同年岩崎通信機 (株) 入社。 1978 年, 岐阜県 (金属試験場) 入庁。現在 (財) ソ フトピアジャパン地域結集型共同研究推進室長。 主に画像認識，CAD/CAM 関連の研究に従事。 電子情報通信学会, 情報処理学会, 映像情報メディ ア学会各会員。 